\title{
PENGEMBANGAN KOMPETENSI DAN PENDIDIKAN BERKELANJUTAN PUSTAKAWAN PTAIN: STUDI KASUS DI PERPUSTAKAAN UIN SUNAN KALIJAGA YOGYAKARTA
}

\author{
${ }^{1)}$ Anis Masruri, ${ }^{2}$ Sodiq A. Kuntoro, ${ }^{3)}$ Suharsimi Arikunto \\ ${ }^{1)}$ UIN Sunan Kalijaga Yogyakarta, ${ }^{2,3)}$ Universitas Negeri Yogyakarta \\ Anismas69@gmail.com, sodiq_azis@uny.ac.id, -
}

\begin{abstract}
Abstrak
Penelitian ini bertujuan mengungkapkan pengembangan kompetensi dan pendidikan berkelanjutan pustakawan UIN Sunan Kalijaga Yogyakarta menurut persepsi pustakawan, pimpinan, dan pengguna perpustakaan. Metode yang digunakan adalah metode kualitatif dengan pendekatan studi kasus di Perpustakaan UIN Sunan Kalijaga Yogyakarta. Hasil penelitian ini adalah sebagai berikut: (1) kompetensi pustakawan UIN Sunan Kalijaga Yogyakarta yang perlu dikembangkan terbagi menjadi enam bidang, yaitu: kompetensi manajerial, kompetensi pengelolaan informasi, kompetensi kependidikan, kompetensi kepribadian, kompetensi sosial, dan kompetensi pengembangan profesi; (2) pendidikan berkelanjutan bagi pustakawan UIN Sunan Kalijaga Yogyakarta dilakukan melalui pendidikan nonformal berbentuk pelatihan dengan mengacu pada prinsip pendidikan orang dewasa (andragogi). Adapun materi yang perlu dipelajari dalam kegiatan pelatihan oleh pustakawan UIN Sunan Kalijaga Yogyakarta meliputi kajian minat dan kebutuhan informasi, seleksi bahan pustaka, pengadaan bahan pustaka, organisasi dan analisis informasi, manajemen perpustakaan, pelayanan informasi, literasi informasi, teknologi informasi, pengembangan kepribadian, dan keterampilan interpersonal.
\end{abstract}

Kata kunci: kompetensi pustakawan, pendidikan berkelanjutan

\section{THE DEVELOPMENT OF ADVANCED EDUCATION AND COMPETENCY FOR THE LIBRARIANS OF ISLAMIC STATE UNIVERSITY: A CASE STUDY IN THE LIBRARY OF SUNAN KALIJAGA STATE ISLAMIC UNIVERSITY YOGYAKARTA \\ ${ }^{1)}$ Anis Masruri, ${ }^{2)}$ Sodiq A. Kuntoro, ${ }^{3)}$ Suharsimi Arikunto \\ ${ }^{1)}$ Sunan Kalijaga State Islamic University Yogyakarta, ${ }^{2,3)}$ Yogyakarta State University, anismas69@gmail.com,sodiq_azis@uny.ac.id, -}

\begin{abstract}
The study was to reveal the development of advanced education and competency for the librarians of Sunan Kalijaga State Islamic University Yogyakarta according to the perception of the librarians, the leaders and the users. The method that the researchers employed was a qualitative method by means of case study approach and the study was conducted in the Library of Sunan Kalijaga State Islamic University. The results of the study were as follows: (1) The competencies for the librarians of Sunan Kalijaga State Islamic Universities that should be developed were divided into six domains namely: managerial competency, information-processing competency, education competency, personality competency, social competency and professional development competency; and (2) The advanced education for the librarians of Sunan Kalijaga State Islamic University should be conducted through a non-formal education in the form of training programs by referring to the principles of andragogy (education for the adult people). However, the materials that should be studied by the librarians of Sunan Kalijaga State Islamic University in the training activities included the interest and information needs analysis, the literary material selection, the literary material procurement, the information organization and analysis, the library management, the information service, the information literacy, the information technology the personality development and the interpersonal skills.
\end{abstract}

Keywords: librarians' competency, advanced education 


\section{PENDAHULUAN}

Undang-Undang Nomor 43 Tahun 2007 tentang perpustakaan, pada bab 1 pasal 1 ayat 8 menyebutkan bahwa pustakawan adalah seseorang yang memiliki kompetensi yang diperoleh melalui pendidikan dan/atau pelatihan kepustakawanan serta mempunyai tugas dan tanggung jawab melaksanakan pengelolaan dan pelayanan perpustakaan. Namun pada kenyataannya, masih banyak pustakawan di Indonesia yang tidak berlatar belakang pendidikan ilmu perpustakaan. Bahkan ada yang beranggapan bahwa pustakawan bukanlah sebuah profesi sehingga tidak memerlukan keahlian khusus. Kondisi tersebut ternyata tidak hanya terjadi di Indonesia saja, tetapi terjadi juga di negara lain. Banyak pustakawan tidak memiliki pendidikan formal bidang perpustakaan baik pada level diploma, master, maupun doktor (MacKellar, 2008 p. 3).

Jika kondisi tersebut terus berlanjut, maka terwujudnya perpustakaan yang berkualitas tentu memerlukan proses yang panjang dan mungkin sulit dipenuhi. Padahal, perpustakaan sebagai pusat sumber belajar, pusat pendidikan, pusat penelitian, pusat informasi, dan pusat konservasi budaya perlu dikelola dengan baik dan profesional. Berbagai kegiatan di perpustakaan pun membutuhkan keahlian khusus yang hanya dapat berhasil baik jika dilakukan oleh pustakawan profesional.

Gorman (2000, p. 14) mensyaratkan profesi pustakawan haruslah orang yang memperoleh pendidikan setingkat master pada lembaga pendidikan perpustakaan yang terakreditasi, dan menerima pelatihan perpustakaan sebagai dasar dalam menjalankan tugasnya. Basuki (1991, p. 8) menjelaskan bahwa syarat profesi pustakawan adalah memiliki keahlian bidang ilmu perpustakaan, dokumentasi dan informasi yang diperoleh melalui pendidikan sebagai dasar dalam melayani masyarakat sesuai dengan visi dan misi lembaga induknya.

Jadi, pustakawan profesional harus berlatar belakang pendidikan ilmu perpustakaan sebagai dasar dalam menjalankan tugastugasnya. Syarat ini diperuntukkan bagi pustakawan pada semua jenis perpustakaan, baik perpustakaan nasional, perpustakaan umum, perpustakaan khusus, perpustakaan sekolah, maupun perpustakaan perguruan tinggi.

Pada pasal 2 dan pasal 3 UU Nomor 43 tahun 2007 disebutkan bahwa perpustaka- an diselenggarakan berdasarkan asas pembelajaran sepanjang hayat, demokrasi, keadilan, keprofesionalan, keterbukaan, keterukuran, dan kemitraan. Perpustakaan berfungsi sebagai wahana pendidikan, penelitian, pelestarian, informasi, dan rekreasi. Adapun tujuan perpustakaan adalah memberikan pelayanan kepada pengguna, meningkatkan kegemaran membaca di kalangan masyarakat, serta meningkatkan wawasan dan ilmu pengetahuan dalam rangka meningkatkan kecerdasan bangsa.

Untuk mewujudkan fungsi dan tujuan perpustakaan tersebut diperlukan pustakawan yang berkompeten. Brophy (2006, p. 98), menjelaskan bahwa "librarians are responsible for delivering services to users and are probably the library's most important asset". Pernyataan ini menegaskan bahwa pustakawan bertanggung jawab memberikan pelayanan pada pengguna perpustakaan dan menjadi bagian terpenting bagi suatu perpustakaan dalam menjalankan peran dan tugasnya di masyarakat.

Tugas pustakawan sebenarnya tidak semudah yang dibayangkan orang pada umumnya. Pustakawan tidak hanya bertugas sebagai penjaga buku, tetapi bertugas sebagai garda pengetahuan (the guardian of knowledge), yaitu menjaga kesinambungan pengetahuan dari generasi ke generasi berikutnya (Hermawan \& Zen, 2006, p 6). Dengan adanya pustakawan yang berkompeten, perpustakaan diharapkan dapat berkembang dengan baik sesuai tujuan lembaga induknya, baik pada lembaga pemerintah, lembaga sosial, maupun lembaga pendidikan.

Pada lembaga pendidikan, termasuk perguruan tinggi, proses pendidikan tidak dapat terselenggara dengan baik jika sivitas akademika tidak didukung sarana pendidikan yang diperlukan. Salah satu sarana pendidikan tersebut adalah perpustakaan yang merupakan tempat bahan pustaka diseleksi, diadakan, dikumpulkan, diolah, dianalisis, disimpan, dan disebarluaskan bagi sivitas akademika (Chernik, 1992, p. 1). Untuk itu, pustakawan harus memiliki kompetensi mengelola perpustakaan dengan sebaik-baiknya agar informasi yang ada di dalamnya dapat dimanfaatkan secara maksimal oleh seluruh sivitas akademika.

Menurut Evans (1995, p. 16), pustakawan pada perpustakaan perguruan tinggi 
bertugas mengelola perpustakaan dalam proses transfer informasi mulai kegiatan identifikasi, seleksi, pengadaan, pengorganisasian, pengolahan, penyimpanan, pemeliharaan, interpretasi, pemanfaatan, dan penyebaran informasi. Proses transfer informasi merupakan siklus yang berlangsung secara terus menerus dan berkesinambungan selama perpustakaan masih ada. Hal itu dilakukan agar perpustakaan dapat berperan sesuai dengan fungsinya yaitu fungsi edukatif, fungsi informatif, fungsi rekreasi, fungsi penelitian, fungsi kultural, dan fungsi penyimpanan karya manusia (Basuki, 1994, p. 3).

Pada perguruan tinggi, setiap mahasiswa, dosen, peneliti, dan seluruh sivitas akademika mendapatkan kesempatan untuk memperluas dan memperdalam pengetahuannya melalui perpustakaan agar dapat mewujudkan tujuan yang telah ditetapkan. Brophy (2006, p. 10) menjelaskan bahwa salah satu tujuan perguruan tinggi adalah mendorong dan memungkinkan sivitas akademika menjadi bagian dari masyarakat demokratis yang memahami hak-hak individu dan bertanggung jawab dalam kehidupan bermasyarakat.

Pustakawan sebagai bagian dari anggota masyarakat hendaknya dapat menyesuaikan diri dan mengembangkan kemampuannya sesuai tuntutan masyarakat yang dari waktu ke waktu terus mengalami perubahan. Sumber informasi juga secara revolusioner terus berubah. Dahulu, informasi hanya dikemas dalam bentuk cetak, kini sebagian berubah berubah ke dalam bentuk digital. Buku, jurnal, dan penerbitan lainnya yang dahulu bercirikan keteraturan waktu terbit, kini sebagian tidak berlaku lagi ketika manusia memasuki wilayah media online, web site atau situs dalam cyberspace.

Oleh karena itu pustakawan perlu memahami peran perpustakaan dalam dunia pendidikan. Menurut Muhadjir (1987, p. 19), pendidikan berfungsi menumbuhkan kreativitas peserta didik, menjaga kelestarian nilainilai insani, nilai-nilai ilahi, dan menyiapkan tenaga kerja yang produktif. Untuk itu, pustakawan perlu berupaya agar perpustakaan dapat mendukung terwujudnya fungsi pendidikan dimaksud. Tentu saja kondisi ini mengharuskan pustakawan memiliki kompetensi yang baik yaitu mampu menunjukkan sikap profesional dalam memberikan pelayanan dan terampil dalam memanfaatkan teknologi infomasi untuk memudahkan para pengguna perpustakaan dalam mengakses informasi yang mereka perlukan.

Namun demikian, realitas yang terjadi di beberapa perpustakaan ditemukan bahwa sebagian pustakawan belum sesuai dengan harapan di atas. Sebagian pustakawan tidak mempersiapkan diri menghadapi perkembangan teknologi informasi. Hal itu terjadi karena pada awalnya mereka tidak berencana menjadi pustakawan atau meskipun dari awalnya berencana menjadi pustakawan, tetapi hal-hal yang berhubungan dengan teknologi informasi dan perkembangannya itu belum mereka pelajari dengan baik. Untuk itu, pustakawan dituntut mengembangkan dirinya melalui berbagai jalan, misalnya melalui pelatihan, seminar, studi banding, dan bentuk pendidikan berkelanjutan lainnya (Wilson \& Tauber, 1966, p. 20).

Pustakawan dituntut memiliki kinerja yang tinggi dan didukung kompetensi yang memadai. Kinerja merupakan hasil kerja seseorang di mana hasil kerja tersebut harus dapat ditunjukkan buktinya secara konkrit dibandingkan dengan standar yang telah ditentukan (Sedarmayanti, 2011, p. 260). Adapun kompetensi yang dimaksud adalah pengetahuan, sikap, kemampuan dan karakteristik yang berhubungan dengan tingkat kinerja suatu pekerjaan seperti pemecahan masalah dan pemikiran analitik (Dewiyana, 2006, p. 22).

Kompetensi pustakawan sangat diperlukan untuk mewujudkan kualitas perpustakaan. Dengan kata lain, sukses tidaknya penyelenggaraan perpustakaan banyak tergantung pada kompetensi pustakawannya. Dengan demikian dapat dikatakan bahwa pustakawan merupakan kunci utama dalam berkualitas atau tidaknya sebuah perpustakaan. Kompetensi pustakawan adalah kemampuan seseorang untuk melaksanakan suatu pekerjaan atau tugas kepustakawanan yang dilandasi atas pengetahuan, keterampilan, dan sikap (Khoo, 2005, p. 1). Senada dengan pengertian sebelumnya, Special Libraries Association mengatakan bahwa "competencies are a combination of skill, knowledge, and behaviour important for organizational success, personal performance and career development" (Special Library Association, 1998, p. 4).

Dari penjelasan tersebut dapat dipahami bahwa kompetensi pustakawan merupa- 
kan kombinasi antara keterampilan, pengetahuan dan tingkah laku yang penting untuk keberhasilan suatu organisasi, kinerja pegawai dan pengembangan karir di perpustakaan. Kompetensi pustakawan dapat digunakan sebagai syarat bagi seseorang untuk dianggap mampu dalam melaksanakan tugas-tugasnya di perpustakaan. Kompetensi pustakawan tersebut dapat diwujudkan melalui seperangkat tindakan cerdas, yang dilaksanakan dengan penuh tanggung jawab oleh individu sehingga pekerjaan dapat dilaksanakan secara efektif dan efisien.

Selanjutnya, Basuki (2006, p. 3) menjelaskan bahwa kompetensi pustakawan merupakan pengetahuan dan keterampilan yang dituntut untuk dimiliki oleh seorang pustakawan dalam melaksanakan tugasnya yang sesuai dengan nilai-nilai yang diterapkan oleh satu organisasi dan juga merupakan kemampuan dasar, yang memungkinkan seorang pustakawan tersebut memiliki cara berpikir, bertingkah laku, dan membuat generalisasi dalam situasi apapun, dan juga dapat menemukan jalan dalam menyelesaikan kesulitan yang berpotensi untuk berlangsung dalam waktu relatif lama.

Kompetensi pustakawan menurut Special Library Association seperti yang dijelaskan di atas, dibagi menjadi dua bagian, yaitu kompetensi profesional dan personal. Kompetensi profesional berhubungan dengan pengetahuan pustakawan dalam hal sumber informasi, akses terhadap informasi, teknologi, manajemen dan penelitian dan kemampuan untuk menggunakan pengetahuan yang dimilikinya sebagai dasar dalam menyediakan layanan perpustakaan dan informasi. Kompetensi personal merepresentasikan sekumpulan keterampilan, sikap dan nilai yang memungkinkan pustakawan dapat bekerja secara efisien, menjadi komunikator yang baik, bersedia belajar secara terus menerus sepanjang karir mereka, menunjukkan nilai tambah dalam kontribusi yang mereka berikan, dan dapat bertahan dalam dunia kerja yang baru.

Hampir sama dengan penjelasan di atas, Daryono (2010, p. 2) menjelaskan bahwa kompetensi pustakawan dapat dibedakan menjadi dua, yaitu (a) kompetensi fungsional yaitu pengetahuan pada sumber-sumber informasi, teknologi, manajemen, penelitian yang digunakan untuk menyediakan layanan, (b) kompetensi personal yaitu keterampilan dan perilaku yang dimiliki pustakawan agar dapat bekerja secara efektif sebagai komunikator, meningkatkan kemampuan dan dapat bertahan terhadap berubahan dan perkembangan jaman. Dalam penjelasan lebih lanjut, Daryono mengatakan bahwa jenis kompetensi dapat dibedakan menjadi dua (a) soft competency yaitu berkaitan erat dengan kemampuan mengatur pekerjaan dan berinteraksi dengan orang lain, sebagai contoh adalah kemampuan memimpin dan kemampuan berkomunikasi, (b) hard competency yaitu yang berkaitan dengan kemampuan fungsional atau teknis suatu pekerjaan, sebagai contoh kemampuan mengklasifikasi, membuat abstrak, melayani pengguna, penelusuran informasi dan sebagainya.

Menurut Ashcroft dan Osa yang dikutip oleh Khoo (2005, p. 2), teknologi baru dan perkembangannya yang sangat cepat berimplikasi pada tugas-tugas pustakawan dan profesional informasi yang mengharuskan mereka bersikap fleksibel dalam mengadaptasi dan mengadopsi keterampilan dan strategi baru untuk menangani segala tugas-tugasnya. Dalam lingkungan kerja pustakawan dan profesional informasi terdapat beberapa karakteristik sebagai berikut: (1) Kompetisi (Competition), artinya, pustakawan dan profesi informasi menghadapi kompetisi dalam menjalankan tugas-tugasnya dengan profesi lain, misalnya profesi teknologi informasi, profesi bisnis yang masuk ke lengkungan kerja di perpustakaan; (2) Perubahan dan lingkungan yang tidak menentu (changing and turbulent environment) dari lembaga induknya, artinya kebijakan-kebijakan lembaga induk yang seringkali berubah akan membuat pustakawan dan profesi informasi akan mendapat tekanan yang terus menerus; (3) Status layanan informasi yang tidak menentu (uncertain status of the information service), yang dipandang oleh lembaga induknya sebagai unit yang hanya dapat menggunakan biaya tanpa menghasilkan; dan (4) Perubahan teknologi yang cepat (rapidly changing technology) serta pertumbuhan produk-produk baru secara terus menerus and continuous introduction of new products.

Dalam rancangan peraturan pemerintah tentang standar nasional perpustakaan, kompetensi pustakawan dibagi menjadi dua yaitu kompetensi profesional dan kompetensi personal. Kompetensi profesional mencakup 
aspek pengetahuan, keahlian, dan sikap kerja, sedangkan kompetensi personal mencakup aspek kepribadian dan interaksi sosial.

Selanjutnya, untuk mengetahui kinerja dan kompetensi pustakawan secara spesifik dapat dilakukan dengan cara bertanya secara langsung kepada pustakawan sebagai penyedia layanan, kepada pimpinan perpustakaan, dan kepada pengguna sebagai penerima layanan perpustakaan. Pelayanan perpustakaan yang diharapkan tentu saja adalah pelayanan yang berkualitas. Kualitas pelayanan merupakan tingkat keunggulan yang diharapkan dalam memenuhi kebutuhan pelanggan (Tjiptono, 2000 , p. 59). Jadi, kualitas pelayanan perpustakaan ini tergantung pada kinerja dan kompetensi pustakawan dalam memberikan pelayanan sesuai dengan harapan penggunanya.

Perpustakaan UIN Sunan Kalijaga Yogyakarta sebagai salah satu jenis perpustakaan perguruan tinggi, khususnya perguruan tinggi agama Islam, berupaya menyelenggarakan pelayanan perpustakaan berdasarkan visi yang telah disusun. Visi perpustakaan ini adalah mengembangkan Perpustakaan UIN Sunan Kalijaga Yogyakarta menjadi perpustakaan penelitian berbasis keislaman dan keilmuan. Visi ini disusun mengacu pada visi UIN Sunan Kalijaga Yogyakarta sebagai lembaga induknya di mana pada saat ini tengah mengembangkan kajian-kajian interdisipliner dengan pendekatan integratif dan interkonektif demi meretas dikotomi antara sains dan agama, antara ilmu agama dan ilmu umum (Abdullah, 2006, p. 27).

Menurut Arianto (2012, pp. 29-30), visi perpustakaan diarahkan untuk mewujudkan Perpustakaan UIN Sunan Kalijaga Yogyakarta menuju world class university library. Untuk mewujudkan visi tersebut, Perpustakaan UIN Sunan Kalijaga Yogyakarta berupaya melakukan berbagai pengembangan, di antaranya adalah pengembangan koleksi yang mendukung pendidikan dan penelitian, pengembangan implementasi teknologi mutakhir, pengembangan dan peningkatan fasilitas pelayanan, serta pengembangan pelayanan khusus penyandang difabel.

Sehubungan dengan hal tersebut, pustakawan UIN Sunan Kalijaga Yogyakarta dituntut memiliki kinerja dan kompetensi yang baik agar dapat mengembangkan perpustakaan sesuai rencana. Meskipun dalam hal penyediaan sumber informasi ini Perpus- takaan UIN Sunan Kalijaga Yogyakarta memiliki persamaan dengan perguruan tinggi lainnya, tetapi perpustakaan ini memiliki ciri khas sendiri, yaitu banyaknya sumber informasi informasi berbahasa Arab yang digunakan oleh sivitas akademika. Untuk itu pustakawan UIN Sunan Kalijaga Yogyakarta dituntut memiliki kemampuan bahasa Arab yang baik.

Saat ini, Perpustakaan UIN Sunan Kalijaga Yogyakarta menggunakan teknologi RFID (Radio Frequency Identification Device) dalam proses peminjaman dan pengembalian koleksi secara mandiri melalui MPS (multi purpose station) dan bookdrop. Teknologi ini termasuk teknologi baru di Indonesia, dan Perpustakaan UIN Sunan Kalijaga Yogyakarta telah mendapatkan penghargaan dari Museum Rekor Indonesia sebagai perpustakaan pertama yang menggunakan teknologi ini. Untuk itu, pustakawan dituntut mampu mengoperasikan, memelihara dan mengembangkan program tersebut agar dapat berjalan terus dalam mendukung pelayanan perpustakaan yang berkualitas.

Pustakawan UIN Sunan Kalijaga Yogyakarta juga dituntut berperan sebagai pengajar bagi seluruh pengguna perpustakaan, misalnya mengajarkan bagaimana cara memanfaatkan fasilitas dan informasi yang terdapat di perpustakaan, cara mengunakan OPAC (Online Public Access Catalog) pada saat melakukan penelusuran informasi, cara melakukan transaksi peminjaman dan pengembalian bahan pustaka secara mandiri, cara mencari informasi melalui jurnal elektronik, cara menggunakan buku-buku referens, dan sebagainya. Pengajaran tentang hal-hal tersebut di atas dilakukan pustakawan pada saat pendidikan pengguna perpustakaan.

Namun demikian, semua tuntutan dan harapan di atas, belum semuanya dapat dipenuhi oleh pustakawan UIN Sunan Kalijaga Yogyakarta. Berdasarkan observasi awal yang peneliti lakukan, di Perpustakaan UIN Sunan Kalijaga Yogyakarta, terdapat 21 orang pustakawan. Dari 21 pustakawan tersebut, hanya 7 orang pustakawan yang berasal dari program pendidikan ilmu perpustakaan, sedangkan 14 pustakawan lainnya, menjadi pustakawan hanya dengan mengikuti pelatihan-pelatihan perpustakaan saja. Keadaan ini belum sesuai dengan persyaratan pustakawan perguruan tinggi yang ditetapkan dalam Standar Nasio- 
nal Perpustakaan SNP 010: 2011 untuk kategori perpustakaan perguruan tinggi.

Dalam standar tersebut dijelaskan bahwa kualifikasi pengelola perpustakaan perguruan tinggi adalah pustakawan, minimal strata satu di bidang ilmu perpustakaan dan informasi, terlibat aktif dalam organisasi profesi dibuktikan dengan kartu anggota atau sertifikat. Tenaga teknis perpustakaan dengan pendidikan minimal diploma dua serta memperoleh pelatihan kepustakawan dari lembaga pendidikan dan pelatihan yang terakreditasi (Perpustakaan Nasional R.I, 2011, p. 6).

Dengan demikian, pustakawan UIN Sunan Kalijaga Yogyakarta dituntut untuk terus mengembangkan kompetensinya melalui pendidikan berkelanjutan agar kesenjangan antara pengetahuan yang dimiliki dengan kebutuhan yang diperlukan dalam menjalankan tugas profesi pustakawan tersebut dapat teratasi. Dasgupta dan Satpathi (2006, p. 242) menyatakan sebagai berikut: "continuing education has become essential for each and every type of library professionals. It includes both formal and informal learning situations".

Berdasarkan Surat Edaran Menteri Pendayagunaan Aparatur Negara dan Reformasi Birokrasi Nomor 04 Tahun 2013 tentang Pemberian Tugas Belajar Bagi Pegawai Negeri Sipil, pendidikan lanjut melalui pendidikan formal ini sulit untuk direalisasikan oleh pustakawan UIN Sunan Kalijaga Yogyakarta karena adanya persyaratan usia maksimal dalam pemberian izin belajar.

Masalah yang muncul kemudian adalah bagaimanakah pengembangan kompetensi pustakawan UIN Sunan Kalijaga Yogyakarta ini dilakukan agar dapat memenuhi tugasnya dengan baik, serta pendidikan berkelanjutan seperti apa yang dapat dilakukan oleh pustakawan UIN Sunan Kalijaga Yogyakarta? Untuk mengetahui kompetensi pustakawan UIN Sunan Kalijaga Yogyakarta yang perlu dikembangkan tentu harus dimulai dari evaluasi terhadap kompetensi yang dimiliki oleh pustakawan UIN Sunan Kalijaga Yogyakarta pada saat ini agar pengembangan kompetensi tersebut dapat dilakukan sesuai dengan kebutuhan.

Menurut Nawawi (2006, p. 109) eva-

luasi dapat dilakukan dengan model 360 derajat, artinya evaluasi terhadap kompetensi pustakawan UIN Sunan Kalijaga Yogyakarta ini dilakukan dengan bertanya kepada pustakawan, pimpinan dan pengguna perpustakaan serta berpedoman pada standar yang ada. Di antara standar kompetensi pustakawan yang dapat digunakan adalah standar kompetensi berdasarkan Keputusan Mendiknas Nomor 25 tahun 2008 dan Keputusan Menteri Tenaga Kerja dan Transmigrasi Republik Indonesia Nomor 83 Tahun 2012 Tentang Penetapan Rancangan Standar Kompetensi Kerja Nasional Indonesia Sektor Jasa Kemasyarakatan, Sosial Budaya, Hiburan dan Perorangan Lainnya Bidang Perpustakaan Menjadi Standar Kompetensi Kerja Nasional Indonesia (SKKNI). Untuk melengkapi beberapa standar di atas, penjabarannya dapat diambil dari sumber-sumber lain, misalnya Keputusan Menpan Nomor 132/KEP/M.PAN/12/2002 tentang Jabatan Fungsional Pustakawan dan Angka Kreditnya, standar yang dikeluarkan oleh Special Library Association, buku pedoman perpustakaan perguruan tinggi, serta sumber-sumber lainnya.

Kajian tentang pendidikan berkelanjutan bagi pustakawan telah dilakukan oleh beberapa penulis dan peneliti terdahulu. Dasgupta \& Satpathi menulis Continuing Education Programmes of Library \& Information Science (LIS) Professionals in the Universities of West Bengal (India) With Special Reference to the University of Calcutta (2006). Kajian ini dimulai dengan kebutuhan pendidikan berkelanjutan untuk profesi pustakawan dalam era modernisasi dan teknologi informasi. Kemudian mereka menjelaskan mengenai aktivitas pendidikan berkelanjutan dan pengembangan profesi di beberapa negara berkembang. Mereka menjelaskan peranan organisasi-organisasi profesi di India dalam kegiatan pendidikan berkelanjutan. Mereka juga menggarisbawahi beberapa universitas dan institut di India yang menjadi pusat dalam kegiatan pendidikan berkelanjutan dan melakukan analisis kritis terhadap aktivitas tersebut terutama di delapan universitas di Bengal Barat yang didasarkan pada hasil survei.

Adomi and Nwalo menulis Prospects for Continuing Professional Education for Library and Information Science Professionals in Nigeria: the Case of Delta State (2003). Penelitian ini dilakukan dengan survei terhadap prospek pendidikan berkelanjutan untuk profesi pustakawan di Nigeria dengan menggunakan Delta State sebagai studi kasusnya. Teknik kuesioner dan wawancara secara bersama-sama digunakan untuk memperoleh 
data. Sejumlah 51 praktisi pustakawan baik pustakawan akademik, publik, perpustakaan khusus dan pusat informasi digunakan sebagai subjek dalam penelitian ini. Hasil penelitian menujukkan bahwa pustakawan masih perlu untuk mengikuti pendidikan berkelanjutan dalam rangka meningkatkan kinerja dan juga memperluas pengetahuan yang diperlukan dalam memberikan pelayanan yang terbaik.

Saechan dengan penelitiannya yang berjudul the Continuing Education Needs of Academic Librarians in the South of Thailand (2001). Penelitian ini disusun untuk mendapatkan gelar doctor pada Simmons College Graduate School of Library and Information Science. Penelitian ini dirancang untuk melakukan investigasi tentang kebutuhan pendidikan berkelanjutan bagi pustakawan akademik di Thailand Selatan dan membandingkan kebutuhan-kebutuhan yang diidentifikasikan oleh pustakawan akademik tersebut dengan kebutuhan yang dipersepsikan oleh pimpinan perpustakaan. Penelitian ini difokuskan pada identifikasi dan analisis kebutuhan pendidikan berkelanjutan mengenai topik-topik yang berhubungan dengan teknologi, penyebaran informasi bagi para pengguna perpustakaan, dan insentif yang diperoleh pustakawan dalam berpartisipasi dalam pendidikan berkelanjutan. Jenis penelitian yang digunakan adalah penelitian kuantittatif dengan menyebarkan angket pada pustakawan akademik dan pimpinan perpustakaan perguruan tinggi atau universitas. Data yang diperoleh melalui angket tersebut dianalisis dengan formulasi frekuensi dan prosentase dan menggunakan SPSS 10.0 for windows. Hasil penelitian menunjukkan bahwa baik kelompok pustakawan maupun pimpinan perpustakaan perguruan tinggi di Thailand Selatan menganggap bahwa kategori internet dan otomasi perpustakaan merupakan topik yang paling penting dalam kegiatan pendidikan berkelanjutan.

Dahlstrom dengan disertasinya yang berjudul Motivation for Participation in Continuing Library Education (1982). Penelitian ini bertujuan untuk menentukan faktor-faktor yang mendorong pustakawan untuk berpartisipasi dalam pendidikan berkelanjutan Amerika Serikat. Penelitian dilakukan dengan menyebarkan angket ke sejumlah pustakawan. Teori motivasi yang digunakan berdasarkan pada teori hirarki kebutuhan menurut Maslow. Hasil penelitian menunjukkan bahwa faktor- faktor yang memotivasi pustakawan untuk berpartisipasi dalam pendidikan berkelanjutan ada beberapa macam, di antaranya tadalah antangan intelektual yaitu ingin mengembangkan kompetensi ytang dimilikinya, ingin meningkatkan pelayanan yang profesional, ingin memberikan pelayanan yang terbaik pada pengguna perpustakaan, ingin meningkatkan salah satu atau beberapa keterampilan khusus yang diminati, adanya komitmen terhadap profesi dan komitmen pribadi sehingga perlu mengembangkan kemampuan yang telah dimilikinya.

Maesaroh, dengan penelitiannya yang berjudul an investigation of the continuing professional development practices of Indonesian academic libraries (2010). Penelitian ini dilakukan untuk penyusunan disertasi pada Curtin University of Technology Faculty of Humanities, Perth, Western Australia. Data penelitian diperoleh dengan menggunakan angket yang disebarkan pada 133 pustakawan yang ada di Indonesia. Analisis data menggunakan frekuensi dan prosentase. Hasil penelitian yang didapatkan dalam disertasi ini adalah bahwa pada umumnya perpustakaan di Indonesia tidak memiliki standar pengembangan profesi secara berkelanjutan. Pustakawan yang mengikuti pendidikan berkelanjutan sebanyak $46.2 \%$, mengikuti program orientasi sebanyak $39.7 \%$, program pelatihan sebanyak $32.8 \%$, mengikuti seminar sebanyak $18.8 \%$.

Permasalahan dalam penelitian ini adalah bagaimanakah pendidikan berkelanjutan yang sesuai dengan karakteristik kompetensi pustakawan UIN Sunan Kalijaga Yogyakarta menurut pendapat pustakawan, pimpinan perpustakaan, pengguna perpustakaan, dan para ahli? Adapun tujuannya adalah pendidikan berkelanjutan yang sesuai dengan karakteristik kompetensi pustakawan UIN Sunan Kalijaga Yogyakarta menurut pendapat pustakawan, pimpinan perpustakaan, pengguna perpustakaan, dan para ahli

\section{METODE}

Penelitian ini menggunakan metode kualitatif dengan pendekatan studi kasus. Peneliti memilih studi kasus dalam penelitian ini, karena pustakawan UIN Sunan Kalijaga Yogyakarta memiliki karakteristik tersendiri jika dibandingkan dengan pustakawan perguruan tinggi lainnya. 
Penelitian dimulai sejak tanggal 25 Juni 2011 s.d tanggal 30 Agustus 2013. Tempat penelitian di Perpustakaan UIN Sunan kalijaga Yogyakarta. Kriteria tempat penelitian ini didasarkan dengan beberapa pertimbangan, yaitu: Pertama, UIN Sunan Kalijaga Yogyakarta merupakan perguruan tinggi yang mengusung ide integratif dan interkonektif baik antara sesama ilmu agama maupun antara ilmu agama dengan ilmu umum serta berupaya menghapuskan atau mengurangi adanya dikotomi keilmuan. Ide yang dikembangkan UIN Sunan Kalijaga Yogyakarta ini berbeda dengan ide yang dikembangkan oleh perguruan tinggi lainnya sehingga ini dapat dikategorikan sebagai ciri khas yang harus dipahami pula oleh pustakawannya. Kedua, Pustakawan UIN Sunan Kalijaga Yogyakarta hanya bekerja di satu perpustakaan saja yaitu Perpustakaan UIN Sunan Kalijaga Yogyakarta yang harus melayani berbagai pengguna perpustakaan dari berbagai fakultas, program studi atau jurusan serta bidang keilmuan yang berbeda-beda, sedangkan pada perguruan tinggi lain, terkadang pustakawan hanya bekerja di perpustakaan fakultas atau bahkan perpustakaan jurusan yang bidang keilmuannya relatif homogen. Ketiga, Perpustakaan UIN Sunan Kalijaga Yogyakarta memiliki kekhasan tersendiri dalam pengembangan koleksi karena harus menyediakan koleksi secara seimbang. Berbeda dengan perpustakaan perguruan tinggi lainnya yang memiliki perpustakaan fakultas, kekuatan koleksi pada bidang tertentu sudah dilakukan oleh perpustakaan fakultas masing-masing. Keempat, Perpustakaan UIN Sunan Kalijaga Yogyakarta telah menerapkan pelayanan mandiri berbasis Radio Frequency Identification Device, yang belum banyak dilakukan oleh perpustakaan perguruan tinggi lainnya.

Dalam penelitian kualitatif tidak menggunakan istilah populasi, tetapi oleh Spradley sebagaimana yang dikutip Sugiyono (2012, p. 297) dinamakan "social situation" atau situasi sosial. Situasi sosial terdari atas tiga elemen yaitu: tempat (place), pelaku (actors) dan aktivitas (activity) yang berinteraksi secara sinergis. Subjek penelitian adalah sumber utama data penelitian, yaitu yang memiliki data mengenai variabel-variabel yang diteliti (Azwar, 1999, pp. 34-35). Dalam penelitian ini yang dijadikan subjek penelitian adalah pustakawan, pimpinan, dan pengguna perpustakaan.

Penentuan subjek penelitan dengan menggunakan teknik purposive, yaitu dipilih dengan pertimbangan dan tujuan tertentu. Adapun kriteria yang ditentukan untuk menjadi informan dalam penelitian ini adalah: (1) pustakawan UIN Sunan Kalijaga Yogyakarta yang berlatar belakang pendidikan ilmu perpustakaan dan pustakawan impassing. (2) pimpinan perpustakaan UIN Sunan Kalijaga Yogyakarta yang terdiri dari kepala perpustakaan dan kepala sub bagian tata usaha perpustakaan. (3) pengguna aktif perpustakaan UIN Sunan Kalijaga Yogyakarta baik dari unsur dosen maupun mahasiswa.

Selanjutnya tidak menutup kemungkinan informasi juga diperoleh dengan teknik snowball, yaitu teknik pemilihan informan yang dimulai dari satu informan yang dijadikan informan kunci, kemudian atas dasar rekomendasinya mencari informasi yang masih dianggap belum cukup kepada orang yang telah ditunjuk oleh informan sebelumnya. Penentuan informan dianggap telah mencukupi apabila telah sampai pada taraf "redundancy" (kelebihan), artinya apabila penambahan informan tidak mampu mem-perkaya informasi yang diperlukan maka bisa dihentikan untuk persoalan tersebut (Sugiyono, 2012, p. 302).

Teknik pengumpulan data merupakan langkah yang paling utama dalam penelitian, karena tujuan utama dari penelitian adalah mendapatkan data. Tanpa mengetahui teknik pengumpulan data, maka peneliti tidak akan mendapatkan data yang memenuhi standar data yang ditetapkan (Sugiyono, 2012, p. 308). Teknik pengumpulan data yang digunakan adalah observasi partisipan (participant observation), wawancara mendalam (in-depth interview), dan dokumentasi. Sedangkan instrumen yang digunakan adalah panduan observasi, pedoman wawancara, dan alat-alat rekam audio dan video. Hal tersebut di atas di-lakukan oleh peneliti sendiri sebagai instrumen utama.

Pengujian keabsahan data dalam penelitian kualitatif meliputi uji credibility (validitas internal), transferability (validitas eksternal), dependability (reliabilitas), dan confirmability (objektivitas) (Sugiyono, 2012, p. 364). 
Uji kredibilitas data atau kepercayaan terhadap data hasil penelitian kualitatif antara lain dilakukan dengan perpanjangan pengamatan, peningkatan ketekunan dalam penelitian, triangulasi, diskusi dengan teman sejawat, analisis kasus negatif, menggunakan bahan referensi, dan member check (Sugiyono, 2012, p. 365).

Uji transferability berkenaan dengan pertanyaan, sampai mana hasil penelitian dapat diterapkan atau digunakan dalam situasi lain. Bagi peneliti naturalistik, nilai transfer bergantung pada pemakai, hingga manakala hasil penelitian tersebut dapat digunakan dalam konteks dan situasi sosial lain.

Dependability dalam penelitian kuantitatif disebut reliabilitas. Suatu penelitian yang reliabel adalah apabila orang lain dapat mengulangi/mereplikasi proses penelitian tersebut. Dalam penelitian kualitatif, uji dependability dilakukan dengan melakukan audit terhadap keseluruhan proses penelitian.

Pengujian confirmability dalam penelitian kuantitatif disebut dengan uji objektivitas penelitian. Penelitian dikatakan objektif bila hasil penelitian telah disepakati banyak orang. Dalam penelitian kualitatif, uji confirmability mirip dengan uji dependability, sehingga pengujiannya dapat dilakukan secara bersamaan. Menguji confirmability berarti menguji hasil penelitian, dikaitkan dengan proses yang dilakukan. Bila hasil penelitian merupakan fungsi dari proses penelitian yang dilakukan, maka penelitian tersebut telah memenuhi standar confirmability. Dalam penelitian, jangan sampai proses tidak ada, tetapi hasilnya ada (Sugiyono, 2012, p. 374).

Analisis data adalah proses mencari dan menyusun secara sistematis data yang diperoleh dari hasil wawancara, catatan lapangan, dan bahan-bahan lain, sehingga dapat mudah dipahami dan temuannya dapat diinformasikan kepada orang lain. Pada prinsipnya kegiatan analisis data dilakukan bersamaan dengan proses pengumpulan data dan dilanjutkan setelah semua data terkumpul. Analisis data yang digunakan berdasarkan data analisis interaktif sebagaimana dikembangkan Miles \& Huberman (1992). Data yang dapat dikumpulkan pada waktu awal penelitian langsung dicatat untuk dianalisis. Analisis data bersifat induktif/kualitatif.

Analisis data dalam penelitian kualitatif, dilakukan pada saat pengumpulan data berlangsung dan setelah selesai pengumpulan data dalam periode tertentu. Pada saat wawancara, peneliti sudah melakukan analisis terhadap jawaban yang diwawancarai. Bila jawaban yang diwawancarai setelah dianalisis terasa belum memuaskan, maka peneliti akan melanjutkan pertanyaan lagi, sampai tahap tertentu, diperoleh data yang dianggap kredibel. Data yang diperoleh dari lapangan jumlahnya cukup banyak, untuk itu maka perlu dicatat secara teliti dan rinci. Semakin lama peneliti ke lapangan, maka jumlah data akan semakin banyak, kompleks dan rumit. Untuk itu perlu segera dilakukan analisis data melalui reduksi data.

Reduksi data diartikan sebagai proses pemilihan, pemusatan perhatian pada penyederhanaan, pengabstrakan dan trasformasi data kasar yang didapat dari catatan-catatan tertulis di lapangan. Selama pengumpulan data berlangsung, terjadilah tahapan reduksi, selanjutnya membuat ringkasan, mengkode, menelusuri tema dan menulis memo tentang hal-hal yang dianggap penting dan mendukung dalam mendapatkan jawaban-jawaban yang ingin diketahui.

Setelah data direduksi, maka langkah selanjutnya adalah men-display-kan data. Dalam penelitian kualitatif, penyajian data bisa dilakukan dalam bentuk uraian singkat, bagan, hubungan antar kategori, flowchart dan sejenisnya.

Penarikan kesimpulan dalam analisis data kualitatif menggunakan interprestasi dalam bentuk uraian kalimat yang diperluas guna mendapatkan analisis yang berlanjut, berulang, dan terus menerus. Kesimpulan final mungkin belum muncul sampai pengumpulan data terakhir, tergantung pada besarnya kumpulan-kumpulan catatan lapangan, pengkodeannya, dan penyimpanannya. Dengan demikian, kesimpulan dalam penelitian kualitatif mungkin dapat menjawab rumusan masalah yang dirumuskm sejak awal, tetapi mungkin juga tidak, karena masalah dan rumusan masalah dalam penelitian kualitatif masih bersifat sementara dan akan berkembang setelah peneliti berada di lapangan. Kesimpuan dalam penelitian kualitatif adalah merupakan temuan baru yang sebelumnya belum pernah ada. Temuan dapat berupa deskripsi atau gambaran suatu objek yang sebelumnya masih remang-remang atau gelap sehingga setelah diteliti menjadi jelas, dapat berupa hubungan 
kausal atau interaktif, hipotesis, atau teori (Sugiyono, 2012, p. 343).

\section{HASIL DAN PEMBAHASAN}

\section{Realitas Kompetensi Pustakawan UIN Sunan Kalijaga Yogyakarta}

Seperti yang telah dijelaskan di atas, Perpustakaan UIN Sunan Kalijaga Yogyakarta yang berperan sebagai pendukung utama kegiatan tri dharma perguruan tinggi yaitu pendidikan, penelitian dan pengabdian masyarakat itu membutuhkan pengelolaan yang baik dan profesional. Tanpa pengelolaan yang baik dan profesional, peran perpustakaan tersebut sulit dapat diwujudkan. Pengelolaan yang baik hanya dapat dilakukan jika sumber daya manusianya memiliki kompetensi manajerial yang baik. Sumber daya manusia yang utama di perpustakaan tentu saja adalah pustakawan yang telah diakui keberadaannya oleh pemerintah dan masyarakat, serta telah menyandang jabatan tenaga fungsional.

Di Perpustakaan UIN Sunan Kalijaga Yogyakarta saat ini, terdapat 21 pustakawan seperti yang telah tercantum dalam tabel 5 di atas. Seluruh pustakawan UIN Sunan Kalijaga Yogyakarta adalah pegawai negeri sipil dengan golongan, pangkat, dan latar belakang pendidikan yang berbeda-beda. Hal ini seperti yang disampaikan oleh Kasubag Administrasi Perpustakaan sebagai berikut:

Dari 21 orang pustakawan tersebut, hanya 7 orang pustakawan yang berlatar belakang pendidikan ilmu perpustakaan, selebihnya berasal dari latar belakang pendidikan yang bermacam-macam. Ada yang berasal dari Fakultas Ushuluddin, Fakultas Adab, Fakultas Tarbiyah, Fakultas Sosial dan Politik, Fakultas Hukum, Fakultas Sastra dan lain-lain (wawancara dengan Pamuji, pada tanggal 15 Juli 2013).

Kondisi ini tentu saja belum sesuai dengan tuntutan profesi yang diperlukan dalam mengelola perpustakaan, seperti yang dijelaskan oleh Mortimer (2007, p. 174), bahwa dalam bidang perpustakaan, profesional dapat diartikan sebagai "having a university or equivalent qualification in librarianship or information management, performing work at a professional level". Pustakawan harus memiliki kualifikasi pendidikan setingkat universitas atau yang setara dengan uni- versitas dalam bidang ilmu perpustakaan atau manajemen informasi agar dapat melakukan pekerjaan pada tingkat atau taraf profesional. Dengan demikian, dilihat dari kualifikasi latar belakang pendidikannya, hanya ada sekitar 33, 33\% dari keseluruhan pustakawan UIN Sunan Kalijaga Yogyakarta yang dapat dikatakan sebagai pustakawan profesional. Padahal, pustakawan profesional menjadi syarat utama memiliki kompetensi manajerial.

Realitas kompetensi pustakawan UIN Sunan Kalijaga Yogyakarta dilihat dan dievaluasi berdasarkan persepsi pustakawan, pimpinan perpustakaan, dan pengguna perpustakaan dengan mengacu pada standar kompetensi yang dikeluarkan oleh Kepmendiknas Nomor 25 Tahun 2008, dan Kepmenakertrans Nomor 82 Tahun 2012. Hasil evaluasi tersebut menunjukkan bahwa kompetensi pustakawan UIN Sunan Kalijaga Yogyakarta belum memiliki kompetensi yang cukup untuk mengelola perpustakaan terutama pada bidang manajerial, bidang pengelolaan informasi, bidang kependidikan, bidang kepribadian, bidang sosial, dan bidang pengembangan profesi.

Dalam bidang manajerial, pustakawan UIN Sunan Kalijaga Yogyakarta belum mampu membuat perencanaan yang baik sehingga terkadang kegiatan perpustakaan yang sebenarnya penting tetapi tidak dapat dilaksanakan. Menurut pandangan informan dari unsur pustakawan yang bertugas pada bagian pengolahan bahan pustaka, tidak semua pustakawan UIN Sunan Kalijaga Yogyakarta berkompeten dalam membuat perencanaan, baik perencanaan pada tingkatan mikro, yaitu berhubungan dengan tugas yang menjadi tanggung jawabnya maupun perencanaan pada tingkatan makro, yaitu berhubungan dengan pengembangan perpustakaan secara menyeluruh. Ia mengatakan sebagai berikut:

Pustakawan UIN Sunan Kalijaga Yogyakarta seringkali mengalami kesulitan untuk merencanakan tugas-tugas yang akan dilakukan, meskipun sebenarnya tugas-tugas itu sudah biasa dilakukan. Kesulitan pustakawan dalam perencanaan ini tidak saja diakui oleh pustakawan sendiri, tetapi juga diakui oleh para pimpinan perpustakaan, sehingga terkadang perencanaan dilakukan oleh pihak lain. Contoh yang paling konkrit adalah pada saat penyusunan Ren- 
cana Induk Pengembangan (RIP) Perpustakaan UIN Sunan Kalijaga Yogyakarta. Tim khusus yang dibentuk untuk menyusun RIP tersebut terdiri dari para dosen khususnya dosen ilmu perpustakaan, sedangkan pustakawan UIN Sunan Kalijaga Yogyakarta tidak dilibatkan (wawancara dengan Khotimah pada tanggal 26 Juni 2013).

Dari penjelasan pustakawan di atas, tampaknya kompetensi pustakawan dalam bidang manajerial khususnya dalam bidang perencanaan belum diakui sepenuhnya oleh pimpinan di lingkungan UIN Sunan Kalijaga Yogyakarta.

Dalam bidang pengelolaan informasi, pustakawan UIN Sunan Kalijaga masih perlu meningkatkan kemampuan bahasa asing agar dapat digunakan untuk menyeleksi, mengadakan, dan mengolah bahan pustaka dengan tepat. Kemampuan teknologi informasi juga masih perlu ditingkatkan agar dapat digunakan sebagai sarana dalam pengelolaan informasi. Dalam bidang kependidikan, pustakawan masih belum memiliki bekal yang cukup baik untuk mengajar literasi informasi sebagai dasar pendidikan sepanjang hayat bagi pengguna perpustakaan, terutama dari kalangan mahasiswa. Dalam bidang kepribadian, pustakawan UIN Sunan Kalijaga Yogyakarta masih perlu mengenali kemampuan dan kelemahan diri, meningkatkan motivasi dan memperbaiki sikapnya agar dapat memberikan pelayanan yang berkualitas. Dalam bidang sosial, pustakawan UIN Sunan Kalijaga belum mampu menerapkan prinsipprinsip berinteraksi sosial yang humanis dan menyenangkan pengguna perpustakaan. Dalam bidang pengembangan profesi, pustakawan UIN Sunan Kalijaga Yogyakarta belum mampu memahami etika profesi yang digunakan sebagai dasar dalam menjalankan tugas dan kewajibannya di perpustakaan.

Menurut persepsi pustakawan, pimpinan dan pengguna perpustakaan, kompetensi-kompetensi tersebut perlu dikuasai dengan sebaik-baiknya agar pustakawan UIN Sunan Kalijaga Yogyakarta mendapat kepercayaan dari pimpinan dan dilibatkan dalam setiap proses perencanaan yang sangat menentukan bagi pengembangan perpustakaan. Pustakawan UIN Sunan Kalijaga Yogyakarta juga diharapkan memiliki wawasan keilmu- wan yang luas, kemampuan bahasa asing yang baik, penguasaan teknolgi informasi sehingga dapat digunakan sebagai dasar dalam pengelolaan informasi di perpustakaan. Di samping itu dengan peningkatan kompetensi, pustakawan UIN Sunan Kalijaga Yogyakarta dapat memberikan pelayanan yang terbaik dan berkualitas bagi pengguna perpustakaan. Pelayanan yang baik dan berkualitas tersebut dapat mewujudkan kepuasan pengguna perpustakaan, dan kepuasan pengguna perpustakaan dapat meningkatkan citra perpustakaan dan citra pustakawan sebagai tenaga profesional.

\section{Karakteristik Kompetensi Pustakawan UIN Sunan Kalijaga Yogyakarta yang Ideal}

Berdasarkan persepsi pustakawan, pimpinan dan pengguna perpustakaan, karakteristik kompetensi pustakawan UIN Sunan Kalijaga Yogyakarta yang ideal adalah sebagai berikut.

Dalam bidang manajerial, kompetensi ideal yang harus dimiliki pustakawan UIN Sunan Kalijaga Yogyakarta meliputi: (1) kemampuan menyusun perencanaan baik perencanaan jangka pendek, jangka menengah maupun jangka panjang, kemampuan menyusun standar operasional prosedur untuk semua kegiatan perpustakaan, dan kemampuan menyusun berbagai kebijakan, (2) kemampuan mengorganisasi sumber daya, kemampuan berkoordinasi, dan kemampuan bekerja sama dengan orang lain, (3) kemampuan menggerakkan orang lain, kemampuan memimpin, kemampuan memberdayakan aset perpustakaan untuk kepentingan pengguna, (4) kemampuan melakukan pengawasan.

Dalam bidang pengelolaan informasi, kompetensi ideal yang harus dimiliki pustakawan UIN Sunan Kalijaga Yogyakarta, meliputi (1) kemampuan melakukan kajian kebutuhan pengguna, (2) kemampuan melakukan seleksi informasi, (3) kemampuan pengadaan koleksi, (4) kemampuan mengevaluasi otoritas koleksi, pengarang, dan penerbit, (5) kemampuan mengorganisasi informasi, (6) kemampuan menganalisis subjek, (7) kemampuan bahasa asing khususnya bahasa Inggris dan bahasa Arab, 8) kemampuan mengelola OPAC dan teknologi informasi secara umum, dan 9) kemampuan memberikan pelayanan yang berorientasi pada kepuasan pengguna perpustakaan. 
Dalam bidang kependidikan, kompetensi ideal yang harus dimiliki pustakawan UIN Sunan Kalijaga Yogyakarta meliputi (1) kemampuan menjadi mediator antara informasi dan pengguna perpustakaan, (2) kemampuan memberikan pendidikan pengguna, (3) kemampuan memahami teori belajar, (4) kemampuan memberikan literasi informasi sebagai dasar pendidikan sepanjang hayat, (5) kemampuan menyediakan informasi yang tepat sebagai sumber belajar, (6) kemampuan mendukung proses belajar mengajar, terutama yang dilaksanakan di perpustakaan.

Dalam bidang kepribadian, kompetensi ideal yang harus dimiliki pustakawan UIN Sunan Kalijaga Yogyakarta meliputi: (1) memiliki integritas dan kejujuran, (2) berpenampilan fisik yang menarik, (3) memiliki motivasi sebagai pustakawan profesional, (4) memiliki kesadaran dan pengendalian diri yang baik, (5) kemampuan memahami kepribadian orang lain, dan (6) memiliki kecerdasan emosi yang baik.

Dalam bidang sosial, kompetensi ideal yang harus dimiliki pustakawan UIN Sunan Kalijaga Yogyakarta meliputi (1) kemampuan berhubungan dengan orang lain, (2) kemampuan bekerja sama dengan orang lain, (3) kemampuan memberikan pelayanan prima kepada pengguna perpustakaan, (4) kemampuan memberikan pelayanan humanis, (5) kemampuan berkomunikasi khususnya etika berkomunikasi menurut Islam yaitu qawl ma'rufa, qawl maysura, qawl sadida, qawl layyina, dan qawl karima.

Dalam bidang pengembangan profesi, kompetensi ideal yang harus dimiliki pustakawan UIN Sunan Kalijaga Yogyakarta adalah pemahaman yang mendalam terhadap kode etik pustakawan agar pustakawan bekerja secara teratur dan profesional. Kode etik ini juga dapat menjadi rambu-rambu bagi pustakawan dalam menjalankan tugasnya seharihari.

\section{Pendidikan Berkelanjutan yang Sesuai dengan Karakteristik Kompetensi pustakawan UIN Sunan Kalijaga Yogyakarta}

Berdasarkan pembahasan di atas, model pendidikan berkelanjutan yang dapat dilakukan pustakawan UIN Sunan Kalijaga Yogyakarta adalah melalui pendidikan non formal. Secara lebih spesifik pendidikan non formal yang dimaksudkan adalah pelatihan dengan memperhatikan prinsip-prinsip pendidikan orang dewasa.

Pustakawan sebagai orang dewasa harus dilibatkan dalam penyusunan materi pelatihan dengan berdasarkan pada kebutuhan pustakawan itu sendiri. Adapun materi pelatihan yang perlu diberikan kepada pustakawan UIN Sunan Kalijaga Yogyakarta meliputi: (1) kajian minat dan kebutuhan informasi pengguna perpustakaan, (2) seleksi bahan pustaka, (3) pengadaan bahan pustaka, (4) organisasi dan analisis informasi, (5) manajemen perpustakaan, (6) pelayanan informasi, (7) literasi informasi, (8) teknologi informasi, (9) pengembangan kepribadian, dan (10) keterampilan interpersonal.

Metode pelatihan yang yang seharusnya digunakan dalam pendidikan berkelanjutan oleh pustakawan UIN Sunan Kalijaga Yogyakarta adalah metode ceramah, demonstrasi, metode pemecahan masalah, dan diskusi baik digunakan secara terpisah ataupun digunakan sebagai kesatuan dalam proses pembelajaran, menyesuaikan dengan materi pelatihan yang dipelajari, ketersediaan waktu dan fasilitas, serta kemampuan fasilitator pelatihan.

\section{SIMPULAN DAN SARAN}

\section{Simpulan}

Dari hasil penelitian ditemukan bahwa Pustakawan UIN Sunan Kalijaga Yogyakarta belum memiliki kompetensi yang memadai dalam mengelola perpustakaan sebagai pendukung utama kegiatan pendidikan dan penelitian di lingkungan kampus. Padahal pustakawan merupakan sumber daya yang sangat penting bagi terwujudnya kualitas perpustakaan. Oleh karena itu apabila kompetensi pustakawan ingin ditingkatkan maka diperlukan usaha dari semua pihak, terutama dari pustakawannya sendiri agar tetap memiliki motivasi yang kuat, tidak mengenal lelah, berusaha secara terus menerus meningkatkan dan mengembangkan kompetensinya melalui berbagai cara.

Bagi pustakawan yang tidak mungkin lagi melanjutkan studinya melalui pendidikan formal, pengembangan kompetensi dapat ditempuh melalui pendidikan nonformal. Implikasinya adalah diperlukan perencanaan yang matang dalam pengembangan profesi, serta 
diperlukan dukungan dari para pimpinan dengan memberikan kemudahan dalam perizinan serta bantuan biaya pendidikan. Hasil penelitian juga menjelaskan bahwa pelatihan merupakan salah satu model pendidikan berkelanjutan yang paling diminati pustakawan UIN Sunan Kalijaga Yogyakarta dalam mengembangkan kompetensinya, sehingga diperlukan perencanaan yang matang pula dalam menyiapkan pelatihan sesuai dengan kebutuhan yang diharapkan.

Kebutuhan pustakawan terhadap materi pelatihan perlu dilakukan dengan cermat, serta disesuaikan dengan perkembangan: layanan perpustakaan, pengguna perpustakaan, dan teknologi informasi sebagai media dalam pemanfaatan perpustakaan. Tanpa dilakukan analisis kebutuhan pelatihan yang tepat, materi yang diberikan bisa terlalu rendah ataupun terlalu tinggi sehingga tidak banyak memberikan manfaat bagi pustakawan UIN Sunan Kalijaga Yogyakarta. Beberapa ketentuan yang harus diperhatikan dalam menyusun materi pelatihan di antaranya adalah tingkat kesulitan materi harus sesuai dengan tingkat kemampuan pustakawan, materi yang disusun berisi bahan-bahan yang benar-benar diperlukan pustakawan, media dan fasilitas pembelajaran yang mendukung, serta kemampuan fasilitatornya.

Metode pelatihan yang paling disukai pustakawan UIN Sunan Kalijaga Yogyakarta adalah ceramah, diskusi, dan demonstrasi. Meskipun demikian, fasilitator perlu memilihi metode pengajaran yang lebih menekankan keaktifan peserta. Hal ini perlu mendapatkan perhatian dari para fasilitator dalam mendesain materi dan strategi pembelajaran agar sesuai dengan keinginan pustakawan sehingga dapat tercipta iklim pembelajaran yang baik dan menyenangkan. Situasi dan kondisi yang baik dan menyenangkan dapat menimbulkan motivasi pustakawan untuk berpartisipasi aktif dalam kegiatan pelatihan, dan motivasi yang kuat tersebut dapat mempengaruhi hasil pembelajaran yang lebih baik.

\section{DAFTAR PUSTAKA}

Abdullah, A. (2006). Transformasi IAIN Sunan Kalijaga Yogyakarta menjadi UIN Sunan Kalijaga Yogyakarta. Yogyakarta: UIN Sunan Kalijaga Yogyakarta.
Arianto, M. S. (2012). Perpustakaan UIN Sunan Kalijaga Yogyakarta menuju world class university library. Suka News, Edisi 1 No. 2 OktoberDesember, 28-30.

Azwar, S. (1999). Metode penelitian. Yogyakarta: Pustaka Pelajar.

Basuki, S. (1994). Periodisasi Perpustakaan. Bandung: Remaja Rosdakarya.

Brophy, P. (2006). The academic library. London: Facet Publishing.

Chernik, Barbara E. (1992). Introduction to library services. Englewood, Colorado: Libraries Unlimited Inc.

Daryono. (2010). Kompetensi pustakawan dalam memberikan layanan prima di perpustakaan perguruan tinggi, Jurnal Kepustakawanan Dan Masyarakat Membaca, Vol. 26 No. 2, JuliDesember.

Dasgupta, A \& Satpathi, J. N. (2006). continuing education programmes of lis professionals in The University of Bengal (India). [Versi Elektronik], Proceeding in The Asia-Pacific Conference on Library and Information Education and Practice, Singapore: School of Communication and Information, Nanyang Technology University, 230-246.

Dewiyana, H. (2006). Kompetensi dan kurikulum perpustakaan: paradigma baru dan dunia kerja di era globalisasi informasi. Pustaha: Jurnal Studi Perpustakaan dan Informasi, Vol.2, No.1, Juni, 22-31.

Evans, G. Edward. (1995). Developing library and information center collection. Colorado: Libraries Unlimited.

Hermawan, R \& Zen, Z. (2006). Etika kepustakawanan: suatu pendekatan terhadap kode etik pustakawan Indonesia. Jakarta: Sagung Seto.

Gorman, Michael. (2000). Our enduring values: librarianship in the 21st century. Chicago, IL: American Library Association. 
Knight, G.R. (1982). Issues and alternatives in educational philosophy. New York: Andrews University Press.

Khoo, C. S. (2005). Competencies for new era librarians and information professionals. Singapore: Division of Information Studies School of Communication \& Information Nanyang Technological University. Diambil pada tanggal 22 Januari 2013, dari http://www.lib.usm.my/elmu.equip/co nference/documents/ICOL2005 Paper 2 Christopher Khoo.pdf

Knowles, M. (1986). The adult learner: a neglected species. New York: Gulf Publishing Company.

MacKellar, P. H. (2008). The accidental librarian. New Jersey: Information Today, Inc.

Republik Indonesia. (2003). Undang-Undang RI Nomor 20, Tahun 2003, tentang Sistem Pendidikan Nasional.

Republik Indonesia. (2007). Undang-Undang RI Nomor 43, Tahun 2007, tentang Perpustakaan

Saechan, C. (2001). The continuing education needs of academic librarians in the south of Thailand. Disertasi Doktor,
Simmons College Graduate School of Library and Information Science, 2001).

Sedarmayanti. (2011). Manajemen sumber daya manusia: reformasi birokrasi dan manajemen pegawai negeri sipil. Bandung: Refika Aditama.

Special Libraries Association. (1998). Competencies for special librarians of the 21st century library and information studies programs survey final report. Washington: Special Libraries Association. Di ambil pada tanggal 2 Mei 2013, dari http://www.sla.org/PDFs/Competenci es2003_finallocked.pdf.

Special Libraries Association. (2003). Competencies for information professionals of the 21st century. Diambil pada 2 Mei 2013, dari http://www.sla.org/PDFs/Competenci es2003_revised.pdf.

Sugiyono. (2012). Metode penelitian kombinasi (mixed methods). Bandung: Alfabeta.

Tjiptono, F. (2000). Prinsip-prinsip total quality service. Yogyakarta: Andi Offsett. 